Bangladesh J. Pl. Breed. Genet., 28(1): 17-22, 2015

\title{
DIVERGENCE ANALYSIS BASED ON YIELD AND YIELD CONTRIBUTING TRAITS OF A COLLECTION OF SPRING WHEAT GENOTYPES (Triticum aestivum L.)
}

\author{
M. S. Rahman ${ }^{1}$, L. Ali ${ }^{2}$, A. Sultana ${ }^{1}$, M. Ruhullah ${ }^{1}$ and M. S. Hossain ${ }^{3}$ \\ ${ }^{1}$ Lal Teer Seed Ltd. 108, Bir Uttam C. R. Dutta Road, Dhaka 1205 \\ ${ }^{2}$ Department of Genetics and Plant Breeding, Bangabandhu Sheikh Mujibur Rahman \\ Agricultural University, Salna, Gazipur-1706 \\ ${ }^{3}$ Department of Genetic Engineering and Biotechnology, University of Rajshahi, \\ Rajshahi-6205
}

\begin{abstract}
Genetic diversity among 24 spring wheat genotypes (Varieties/lines) was estimated using Mahalanobis $\mathrm{D}^{2}$-statistics and principal coordinate analysis. The genotypes fell into four clusters of different size. Of the seven different characters spike length and 1000 grain weight had the highest contribution towards the divergence. The highest inter cluster distance was observed between cluster I and III followed by cluster II and III. So, genotypes from the most divergence clusters could be used as parents in hybridization program and are expected to manifest maximum heterosis as well as broad spectrum of variability.
\end{abstract}

Key words: Spring wheat; multivariate analysis; cluster; genetic divergence

DOI: http://dx.doi.org/10.3329/bjpbg.v28i1.27846

\section{INTRODUCTION}

Wheat is the most widely known grown cereal crop in the world, occupying $17 \%$ of crop acreage world over, feeding about $36 \%$ of world population (Bhanupriya et al., 2014) and providing $20 \%$ of the total food calories and protein in human nutrition (Verma et al., 2014). Approximately one-sixth of the total arable land in the world is cultivated with wheat. Whereas paddy is mainly cultivated in Asia, wheat is grown in all the continents of the world.

The improvement program in wheat in Bangladesh first attempt was to increase grain yield and second target to confer resistance to disease and tolerance to abiotic stress like heat, salinity, drought etc. The wheat Research Centre of Bangladesh Agricultural Research Institute (BARI) has already released a good number of varieties suitable for Bangladesh condition and thereby area of cultivation has considerably increased. In Bangladesh wheat was cultivated on an area of .923 million acre during 2009-2010 with a production of $976 \mathrm{~kg} / \mathrm{acre}$ and during 2010-2011 this scenario change in area under production (.885 million acre) but production increases per acreage (1124 $\mathrm{Kg}$ ), (Year book of agricultural statistics, 2012). Thus the major objectives in wheat improvement program are to increase grain yield and to release varieties resistant to biotic and abiotic stresses.

The basic key to bring about the genetic upgrading of wheat relies on hybridization and subsequent selection. In plant breeding program choice of parent is the first step for hybridization. Genetic divergence between the parents is important for 
effective breeding program as the genetically diverged parents are known to produce high heterotic effect and wide segregants for developing high yielding varieties. So, estimation of genetic distance is an important factor for selection of parents in wheat breeding program. In this pathway principal coordinate analysis is a multivariate statistical algorithms aims to estimating distance for all possible combination between used parents in a breeding program. Nevertheless, non hierarchical clustering helps to grouped genotypes into different clusters. Thus, the present study was to conducted to decipher the extent of genetic diversity among wheat genotypes using cluster analysisPCO based methods for selection of parents in hybridization program to obtain desirable segregants in advance generation.

\section{MATERIALS AND METHODS}

The experiment was laid out in a randomized complete block design (RCBD) with three replications at the field laboratory of Department of Genetic Engineering and Biotechnology, Faculty of Agriculture, University of Rajshahi on $1^{\text {st }}$ December. This study was performed with 24 genotypes of spring wheat (Table 1) collected from Regional Wheat Research Center of Bangladesh Agricultural Research Institute, Shyampur, Rajshahi to assess the genetic diversity among the genotypes. Each replication was consisted of 24 plots and each of the plots was $2.0 \mathrm{~m}$ long with five rows. The spacing was $40 \mathrm{~cm}$ between rows and $5 \mathrm{~cm}$ between plants in a row. The space maintained between the plots was $80 \mathrm{~cm}$ and between the replication was one meter. Seeds were sown continuously by hand in rows and after complete emergence; $5 \mathrm{~cm}$ distance was maintained between plant after thinning and gap filling in a row of the plot. Urea, Triple Super Phosphate (TSP), Muriate of Potash (MP), Gypsum and Cow dung were applied at the rate of $220 \mathrm{Kg}, 180 \mathrm{Kg}, 50 \mathrm{Kg}, 120 \mathrm{Kg}$ and $6000 \mathrm{Kg} / \mathrm{ha}$, respectively.

Data were recorded on individual plant basis from 10 randomly selected plants of each genotype from the five rows per plot in each replication. Among the characters studied as yield contributing traits plant height $(\mathrm{cm})$, number of spikes per plant, spike length $(\mathrm{cm})$, number of spikelets per spike, number of grains per spike, 1000 grain weight $(\mathrm{g})$ were recorded on plot basis while the grain yield was recorded in the laboratory after harvesting. Data were subjected to $\mathrm{D}^{2}$ analysis following canonical root method of Rao (1952), which was originally developed by Mahalonobis (1936). All the statistical analysis was carried out using the GENSTAT 5.13 software in IBM computer.

Table 1. List of 24 spring wheat genotypes with their breeder institute and characteristics

\begin{tabular}{|c|c|c|c|}
\hline $\begin{array}{l}\text { Sl. } \\
\text { No. }\end{array}$ & $\begin{array}{l}\text { Varieties / } \\
\text { lines }\end{array}$ & $\begin{array}{l}\text { Breeder } \\
\text { Institute }\end{array}$ & Characteristics \\
\hline 1. & Shatabdi & BARI & $\begin{array}{l}\text { Plant height } 90-100 \mathrm{~cm} \text {, heading days } 65-70 \text { days, maturity } 105-115 \text { days, } \\
\text { excellent tillering capacity, broad, droopy and light green leaf, heat tolerant, more } \\
\text { stay green, Lr } 13+, 1+\text { gene contain, TGW } 46-48 \mathrm{gm} \text {, grain dull color, BpLB } \\
\text { tolerant and rust resistant, yield } 3600-4500 \mathrm{~kg} / \mathrm{ha} \text {, good yield in optimum and late }\end{array}$ \\
\hline 2. & Kanchan & BARI & $\begin{array}{l}\text { Plant height } 100-105 \mathrm{~cm} \text {, heading days } 72-75 \text { days, maturity } 112-116 \text { days, TGW } \\
42-45 \mathrm{gm} \text {, yield } 4000-4500 \mathrm{~kg} / \mathrm{ha} \text {, excellent tillering and high chlorophyll } \\
\text { content., Lr 23+,13+ gene present , BpLB susceptible }\end{array}$ \\
\hline 3. & $\begin{array}{l}\text { Kalyan } \\
\text { Sona }\end{array}$ & IARI & $\begin{array}{l}\text { Plant height } 85-90 \mathrm{~cm} \text {, heading days } 70-75 \text { days, maturity } 110-115 \text { days, TGW } \\
30-35 \mathrm{gm} \text {, yield } 3000-3500 \mathrm{~kg} / \mathrm{ha}\end{array}$ \\
\hline 4. & $\begin{array}{c}\text { BAW- } \\
1082\end{array}$ & BARI & $\begin{array}{l}\text { Plant height } 80-82 \mathrm{~cm} \text {, heading days } 57-60 \text { days, early in maturity, } 100-102 \text { days, } \\
\text { TGW } 45-48 \mathrm{gm}, 46-48 \text { grain per spike, yield } 3800-4000 \mathrm{~kg} / \mathrm{ha} \text {, BpLB tolerant }\end{array}$ \\
\hline
\end{tabular}




\begin{tabular}{|c|c|c|c|}
\hline $\begin{array}{l}\text { Sl. } \\
\text { No. }\end{array}$ & $\begin{array}{l}\text { Varieties / } \\
\text { lines }\end{array}$ & $\begin{array}{l}\text { Breeder } \\
\text { Institute }\end{array}$ & Characteristics \\
\hline 5. & Ananda & BARI & $\begin{array}{l}\text { Plant height } 90-95 \mathrm{~cm} \text {, heading days } 65-70 \text { days, maturity } 102-107 \text { days, TGW } 30 \\
35 \mathrm{gm} \text {, yield } 2000-2500 \mathrm{~kg} / \mathrm{ha}\end{array}$ \\
\hline 6. & Akbar & BARI & $\begin{array}{l}\text { Plant height } 85-90 \mathrm{~cm} \text {, heading days } 65-67 \text { days, maturity } 104-110 \text { days, TGW } 32 \\
35 \mathrm{gm} \text {, yield } 3000-3200 \mathrm{~kg} / \mathrm{ha}\end{array}$ \\
\hline 7. & Seri-82 & CIMMYT & $\begin{array}{l}\text { Plant height } 90-95 \mathrm{~cm} \text {, heading days } 70-75 \text { days, maturity } 105-110 \text { days, TGW } 33- \\
35 \mathrm{gm} \text {, yield } 3000-3500 \mathrm{~kg} / \mathrm{ha}, \operatorname{Lr} 23, \operatorname{Lr} 26 \text { gene contains, slow rusting }\end{array}$ \\
\hline 8. & Inia-66 & CIMMYT & $\begin{array}{l}\text { Plant height } 95-100 \mathrm{~cm} \text {, heading days } 62-65 \text { days, maturity } 102-105 \text { days, TGW } \\
38-40 \text { gm, yield } 3500-4000 \mathrm{~kg}, \operatorname{Lr} 13, \operatorname{Lr} 17 \text { gene present }\end{array}$ \\
\hline 9. & Gourab & BARI & $\begin{array}{l}\text { Plant height } 90-102 \mathrm{~cm} \text {, heading days } 60-65 \text { days, maturity } 102-108 \text { days, BpLB } \\
\text { tolerant and rust resistant, TGW } 40-48 \mathrm{gm}, 45-50 \text { grain per spike, yield } 3600-4800 \\
\mathrm{~kg} / \mathrm{ha} \text {, good in late }\end{array}$ \\
\hline 10. & $\begin{array}{l}\text { BAW- } \\
1083\end{array}$ & BARI & $\begin{array}{l}\text { Plant height } 95-100 \mathrm{~cm} \text {, heading days } 55-60 \text { days, early in maturity, } 95-100 \text { days, } \\
\text { TGW } 45-48 \text { gm, } 35-38 \text { grains } / \text { spike, yield } 4200-4400 \mathrm{~kg} / \mathrm{ha} \text {, BpLB tolerant }\end{array}$ \\
\hline 11. & Prodip & BARI & $\begin{array}{l}\text { Plant height } 95-100 \mathrm{~cm} \text {, heading days } 64-66 \text { days, maturity } 102-110 \text { days, heat and } \\
\text { BpLB tolerant, broad and deep green leaf, TGW } 48-55 \text { gm, good grain filling, } \\
\text { grain bold, white and slender, Lr } 26+, 1+\text { gene contain, yield } 4300-5100 \mathrm{~kg} / \mathrm{ha} \text {, } \\
\text { also good in late }\end{array}$ \\
\hline 12. & Kheri & Local & $\begin{array}{l}\text { Plant height } 115-120 \mathrm{~cm} \text {, TGW } 28-30 \mathrm{gm} \text {, heading days } 75-80 \text { days, maturity } \\
115-118 \text { days, yield } 2000 \mathrm{~kg} / \mathrm{ha} \text {, narrow leaf, more biomass and It has lodging } \\
\text { tendency }\end{array}$ \\
\hline 13. & Sufi & BARI & $\begin{array}{l}\text { Plant height } 90-102 \mathrm{~cm} \text {, heading days } 58-62 \text { days, maturity } 100-110 \text { days, TGW } \\
36-42 \mathrm{gm} \text {, } 50-55 \text { grains per spike, excellent grain filling BpLB tolerant and rust } \\
\text { resistant, heat tolerant, sterility resistant and yield } 3600-4800 \mathrm{~kg} / \mathrm{ha}\end{array}$ \\
\hline 14. & Sonalika & IARI & $\begin{array}{l}\text { Plant height } 90-99 \mathrm{~cm} \text {, heading days } 60-65 \text { days, maturity } 110-115 \text { days, TGW } \\
30-35 \text { gm, yield } 3000-3500 \mathrm{~kg} / \mathrm{ha}\end{array}$ \\
\hline 15. & $\begin{array}{l}\text { BAW- } \\
1056\end{array}$ & BARI & $\begin{array}{l}\text { Plant height } 75-85 \mathrm{~cm} \text {, heading days } 57-64 \text { days, early in maturity, } 95-104 \text { days, } \\
\text { TGW } 40-46 \mathrm{gm} \text {, grain good, } 38-40 \text { grain per spike, yield } 3500-4000 \mathrm{~kg} / \mathrm{ha} \text {, good } \\
\text { ideotype but rusty }(10-20 \mathrm{~S}) \text { and high biomass }\end{array}$ \\
\hline 16. & Balaka & BARI & $\begin{array}{l}\text { Plant height } 96-99 \mathrm{~cm} \text {, heading days } 68-70 \text { days, maturity } 110-115 \text { days, TGW } \\
35-38 \text { gm and yield } 3500-3800 \mathrm{~kg} / \mathrm{ha}\end{array}$ \\
\hline 17. & Barkat & BARI & $\begin{array}{l}\text { Plant height } 90-100 \mathrm{~cm} \text {, heading days } 68-70 \text { days, maturity } 105-112 \text { days, TGW } \\
30-32 \mathrm{gm} \text { and yield } 3000-3300 \mathrm{gm}\end{array}$ \\
\hline 18. & Sourav & BARI & $\begin{array}{l}\text { Plant height } 100-105 \mathrm{~cm} \text {, heading days } 75-80 \text { days, maturity } 112-115 \text { days, late, } \\
\text { heat tolerant, Lr } 26+, 1+\text { gene presence, TGW } 45-46 \mathrm{gm} \text {, grain pale white, bold, } \\
\text { BpLB susceptible and yield } 3800-4000 \mathrm{~kg} / \mathrm{ha}\end{array}$ \\
\hline 19. & $\begin{array}{l}\text { BAW- } \\
1004\end{array}$ & BARI & $\begin{array}{l}\text { Plant height } 102-107 \mathrm{~cm} \text {, heading days } 65-70 \text { days, maturity } 105-115 \text { days, TGW } \\
45-48 \text { gm, grain filling good, yield } 3500-4000 \mathrm{~kg} / \text { ha, very good leaf, } \mathrm{Lr} 13+\text { gene } \\
\text { contain and BpLB tolerant }\end{array}$ \\
\hline 20. & Pavon-76 & CIMMYT & $\begin{array}{l}\text { Plant height } 95-105 \mathrm{~cm} \text {, heading days } 80-85 \text { days, maturity } 108-115 \text { days, TGW } \\
24-30 \text { gm, yield } 2800-3000 \mathrm{~kg} / \mathrm{ha} \text {, LrI, } \operatorname{Lr} 10, \mathrm{Lr} 13, \mathrm{Lr} 46,+ \text { and SR gene contains }\end{array}$ \\
\hline 21. & Bijoy & BARI & $\begin{array}{l}\text { Plant height } 95-105 \mathrm{~cm} \text {, heading days } 60-65 \text { days, maturity } 103-112 \text { days, Heat } \\
\text { tolerant, broad and light green leaf, water logged susceptible at seedling stages, } \\
\text { BpLB disease tolerant and rust resistance, Yield } 4300-4500 \mathrm{~kg} / \mathrm{ha} \text {, good yield in } \\
\text { optimum and late, TGW } 45-52 \mathrm{gm} \text {, good grain filling, grains are white and bold }\end{array}$ \\
\hline 22. & Aghrani & BARI & $\begin{array}{l}\text { Plant height } 90-95 \mathrm{~cm} \text {, heading days } 70-72 \text { days, maturity days } 112-115 \text { days, } \\
\text { TGW } 40-43 \text { gm, yield } 3200-3500 \mathrm{~kg} / \mathrm{ha}\end{array}$ \\
\hline 23. & Sonara-64 & CIMMYT & $\begin{array}{l}\text { Plant height } 88-95 \mathrm{~cm} \text {, heading days } 60-65 \text { days, maturity } 105-115 \text { days, TGW } 28- \\
30 \text { gm, yield } 2800-3000 \mathrm{~kg} / \mathrm{ha} \text {, Lr1 gene containing }\end{array}$ \\
\hline 24. & Protiva & BARI & $\begin{array}{l}\text { Plant height } 100-105 \mathrm{~cm} \text {, heading days } 70-73 \text { days, maturity days } 112-115 \text { days, } \\
\text { TGW } 42-45 \text { gm and Yield } 4200-4500 \mathrm{~kg} / \mathrm{ha}\end{array}$ \\
\hline
\end{tabular}




\section{RESULTS AND DISCUSSION}

Analysis of variance revealed that all the genotypes varied significantly for all the character studied as yield contributing traits.

\section{Cluster analysis}

By the application of non-hierarchical clustering using covariance matrix 24 wheat genotypes for yield contributing traits were grouped into four distinct clusters (Table 2). Similar clustering patterns were reported Baranwal et al., (2013) and Rahman et al., (2015) in wheat. In the present study, cluster I and IV was the largest group, containing eight genotypes followed by cluster II. Cluster III consisted of only one genotype, respectively.

Table 2. Distribution of 24 genotypes in four clusters.

\begin{tabular}{c|c|l}
\hline $\begin{array}{c}\text { Cluster } \\
\text { no. }\end{array}$ & $\begin{array}{c}\text { Total no. of genotypes } \\
\text { in cluster }\end{array}$ & \multicolumn{1}{c}{ Genotypes included in different clusters } \\
\hline I & 8 & $\begin{array}{l}\text { Kalyan Sona, Ananda, Seri-82, Inia-66, BAW-1056, Barkat, } \\
\text { Pavon-76, Sonora-64 }\end{array}$ \\
II & 7 & $\begin{array}{l}\text { Shatabdi, BAW-1082, Akbar, BAW-1083, Sufi, Aghrani, Protiva } \\
\text { III }\end{array}$ \\
IV & 1 & $\begin{array}{l}\text { Kheri } \\
\text { Kanchan, Gourab, Prodip, Sonalika, Balaka, Sourav, BAW-1004, } \\
\text { Bijoy }\end{array}$ \\
\hline
\end{tabular}

\section{Canonical variate analysis}

The Intra and Inter cluster distance are presented in Table 3. It was revealed from the Table that in all cases the inter cluster distances were larger than the intra cluster distances. Cluster distance suggesting wider diversity among the genotypes of different groups. The members of cluster I and III exhibited maximum divergence, as their inter cluster distance was the highest followed between II and III. On the other hand, the minimum genetic divergence was obtained in the members of cluster I and II indicating a close relationships among the genotypes of these clusters. Verma et al., (2014) reported that the inter-cluster values that indicated close relationship were to be considered that hybridization among the genotypes of these clusters would not provide good levels of segregation. It is well recognized that greater the distance between clusters, wider the genetic diversity would be between the genotypes. Therefore, highly divergent genotypes would produce a broad spectrum of segregation in the subsequent generations enabling further selection and improvement. The hybrids developed from the selected genotypes within the limit of compatibility of these clusters may produce desirable transgressive segregants of high magnitude of heterosis.

Table 3. Average intra (Bold) and inter cluster distances $\left(D^{2}\right)$ for 24 wheat genotypes.

\begin{tabular}{c|c|c|c|c}
\hline Clusters & I & II & III & IV \\
\hline I & $\mathbf{0 . 2 8 9}$ & 3.411 & 11.749 & 5.589 \\
& $\mathbf{( 0 . 5 3 8 )}$ & $(1.846)$ & $(3.427)$ & $(2.364)$ \\
II & & $\mathbf{0 . 3 9 6}$ & 10.668 & 3.723 \\
& & $\mathbf{( 0 . 6 2 9 )}$ & $(3.266)$ & $(1.929)$ \\
III & & & $\mathbf{0 . 0 0 0}$ & 9.319 \\
& & & $\mathbf{0 . 0 0 0}$ & $(3.052)$ \\
IV & & & & $\mathbf{0 . 4 4 9}$ \\
& & & & $\mathbf{( 0 . 6 7 0 )}$ \\
\hline
\end{tabular}


[Note: The values on the diagonals (bold) are intra cluster and those on off diagonals are inter cluster distance. Figures in the parentheses are the D-values $\left.\left(D=\sqrt{D^{2}}\right)\right]$

The intra cluster distances of cluster IV were highest (0.449) than the other clusters, suggesting cluster IV included more diverse materials. Therefore, highly divergent genotypes would produce a broad spectrum of segregation in the subsequent generations enabling further selection and improvement. In this present study, it was observed that the cluster I and III as well as II and III were highly diverse. So they were seemed to be more stable.

\section{Cluster means for the characters}

The four clusters showed considerable differences in mean values for different characters under study (Table 4).From the cluster mean values it was found that cluster II had the highest mean values for grain yield (6.32), spike length (10.14), number of spikelets per spike (20.23), number of grains per spike (49.95) with moderately high mean values for remaining characters. This indicates that presence of high yielding genotypes in the cluster II. Cluster III included a single variety named Kheri which exhibited highest mean values for plant height (137.73), number of spikes per plant (8.27) and poor performance for grain yield and other yield contributing characters.

Table 4. Cluster mean values for yield and yield contributing traits in 24 spring wheat genotypes.

\begin{tabular}{l|c|c|c|c}
\hline \multirow{2}{*}{\multicolumn{1}{c|}{ Characters }} & \multicolumn{4}{c}{ Clusters } \\
\cline { 2 - 5 } & I & II & III & IV \\
\hline Plant height (cm) & 90.97 & 94.76 & 137.73 & 99.52 \\
Number of spikes per plant & 4.87 & 5.45 & 8.27 & 5.08 \\
Spike length (cm) & 9.11 & 10.14 & 8.43 & 10.11 \\
Number of spikelets per spike & 19.82 & 20.23 & 20.00 & 19.58 \\
Number of grains per spike & 46.06 & 49.95 & 37.27 & 39.33 \\
1000 Grain weight (g) & 35.49 & 42.93 & 34.19 & 45.35 \\
Grain yield per plant (g) & 5.04 & 6.32 & 3.12 & 5.64 \\
\hline
\end{tabular}

Jamil et al., (2015) reported that based on cluster means, the cluster have been identified for selecting parents for future hybridization programme. The genotypes superior in the cluster may be involve in a multiple crossing programme to recover transgressive segregants with high genetic yield potential.

\section{Contribution of characters towards divergence}

The contribution of individual traits to the total divergence was studied (Table 5). The Table revealed that in vector I, the important traits responsible for genetic divergence in the major axis of differentiation were number of grains per spike $(0.2220)$ and 1000 grain weight $(0.1904)$. On the contrary, in vector II which is the second axis of differentiation spike length (1.2574) number of spikelets per spike (0.3948) and 1000 grain weight $(0.2323)$ were important.

Table 5. Relative contributions of yield and yield contributing traits to the total divergence in 24 spring wheat genotypes.

\begin{tabular}{c|c|c}
\hline Characters & Vector - I & Vector -II \\
\hline Plant height $(\mathrm{cm})$ & +0.1336 & -0.1109
\end{tabular}


Number of spikes per plant

Spike length $(\mathrm{cm})$

Number of spikelets per spike

Number of Grains per spike

1000 Grain weight $(\mathrm{g})$

Grain yield per plant $(\mathrm{g})$

$\begin{array}{ll}-0.8449 & +0.0912 \\ +0.0582 & +1.2574 \\ -0.3233 & +0.3948 \\ +0.2220 & -0.1051 \\ +0.1904 & +0.2323 \\ +0.1791 & -0.0213\end{array}$

The role of spike length and 1000 grain weight for both the vectors were positive across two axes indicating the important components of genetic divergence in these materials. Hossain et al. (2006) found spike length and 1000 grain weight as most contributing character towards the genetic divergence.

\section{Selection of parents}

Genotypically distance parents usually able to produce higher heterosis (Falconer, 1960; Ghaderi et al., 1979). Considering magnitude of genetic distance, magnitude of cluster means for different characters and per se performance it was suggested that the crosses between genotypes belonging to cluster I and III, and II and III would give high manifestation of heterosis as well as wide spectrum of genetic variation in $\mathrm{F}_{2}$ generation. Genotypes included cluster I could be selected for dwarf sized plant, cluster II for longest spike, higher number of grains per spike and moderate grain size and highest grain yield, cluster III for maximum plant height and highest number of spikes per plant and cluster IV for higher spike length, moderate number of spikelets per spike, bold sized grain and higher grain yield.

\section{REFERENCES}

Baranwal, D. K., V. K. Mishra and T. Singh. 2013. Genetic diversity based on cluster and principal component analyses for yield and its contributing characters in wheat (Triticum aestivum L.). Madras Agric. J., 100 (4-6): 320-323.

Bhanupriya, B., N. H. Das, S. Satyanarayana, S. Mukherjee and K. K. Sarker. 2014. Genetic diversity of wheat genotypes based on principal component analysis. Journal of Crop and Weed, 10(2):104-107.

Falconer, D. S. 1960. Introduction to quantitative genetics, Oliver and Bond, London. p. 304.

Ghaderi, A., M. Shishegar, A. Regai and B. Edhaie. 1979. Multivariate analysis of genetic diversity for yield and its components in mungbean. J. American Soc. Hort. Sci. 104: 728-732.

Hossain, M. S., O. I. Joarder, M. M. Rahaman and M. M. Rahaman. 2006. Genetic diversity in some genotypes of spring wheat. Bangladesh J. Environ. Sci. 12: 146149.

Jamil, A., S. Khan, Ubaidullah, M. Zeeshan and M. Zulfiqar Ali. 2015. Cluster analysis, genotypic and phenotypic correlation among yield contributing traits in bread wheat (Triticum aestivum L.) germplasm. International Journal of Modern Agriculture.4 (1).22-29.

Mahalanobis, P. C. 1936. On the generalized distance in statistics. Proc. Nat. Inst. Sci., India. 2: 49-55.

Rahman, M. S., M. S. Hossain, M. K. Akbar, M. S. Islam and L. Ali. 2015. Genetic divergence in spring wheat genotypes (Triticum aestivum L.). Eco-friendly Agril. J. 8(01): 01-03.

Rao, C. R. 1952. Advanced statistical methods in biometric research. John. Willey and Sons. New York. 
Verma, P. N., B. N. Singh, G. Singh, M. K. Singh and T. L. Setter. 2014. Genetic diversity analysis for yield and other agronomic traits in bread wheat under water logged sodic soil condition. Journal of Wheat Research 6(1):51-58.

Year Book of Agricultural Statistics. 2012. Bangladesh Bureau of Statistics (BBS), Statistics and Informatics Division (SID), Ministry of Planning, Government of the People's Republic of Bangladesh. 